Os homens do imaginário nacionalista: representacões da masculinidade em publicações periódicas nacionalistas de direita argentinas durante a longa década de sesenta (19561969)

\title{
Los hombres del imaginario nacionalista: representaciones de la masculinidad en publicaciones periódicas nacionalistas de derecha argentinas durante la larga década del
} sesenta (1956-1969)

\author{
Men in the Nationalist Imaginary: Images of Masculinity in Right-wing Nationalistic \\ Argentine Periodicals During the Long Decade of the Sixties (1956-1969)
}

María Valeria GALVÁN*

Resumen: Luego de la caída del peronismo en 1955, se inició en la Argentina un proceso de cambios políticos, ideológicos y sociales que afectaron el escenario político y las identidades de sus protagonistas. En este contexto, el nacionalismo argentino se vio obligado a redefinir su identidad y su rol político en el nuevo campo de acción. Así, se percibe en las ublicaciones periódicas más representativas $(A y B$ y los boletines de Tacuara) la manera en que el nacionalismo llevó a cabo estas reconfiguraciones a través del uso de dos estereotipos masculinos contrapuestos: el del militante ideal y su opuesto, el ser infrahumano identificado con el adversario político.

Palabras clave: nacionalismo, publicaciones periódicas, estereotipos masculinos, década del sesenta

\begin{abstract}
After the fall of the Peronist government in 1955, the Argentine political scenario and the identities of its main protagonists underwent several political, ideological and social changes. In this context, Argentine Nationalism was forced to redefine its own identity and its new role in the new scenario, in order to survive. Thus, the most representative periodicals ( $A y B$ and the Tacuara magazines) demonstrate how these reconfigurations were made with the help of a particular masculine stereotype and its countertype; i.e., the ideal activist and its opposite, the subhuman that represented the political adversary.
\end{abstract}

Key words: Nationalism, Periodicals, Masculine Stereotypes, Sixties

- Doctora en Historia (UNLP), Magíster en Sociología de la Cultura (IDEAS-UNSAM) y Licenciada en Sociología (UBA) - Instituto del Desarrollo Humano, Universidad Nacional de General Sarmiento, Juan María Gutiérrez 1150, Los Polvorines, Provincia de Buenos Aires, CP: 1613, Argentina. La investigación que resultó en este artículo contó con el financiamiento del CONICET. E-mail: galvan.valeria@googlemail.com 


\section{Introducción}

El arco temporal descripto por los años que van de 1956 a 1969 constituye en Argentina una larga década que, marcada por las transformaciones culturales en la clase media y el advenimiento de novedosas preguntas teóricas y realineamientos políticos en base a nuevas cuestiones coyunturales, se caracterizó por una renovación profunda del campo político e intelectual (SARLO, 2001; SIGAL, 2002; TERÁN, 1993). En este marco, signado por el incipiente proceso de radicalización política que se inició con la caída del gobierno de Juan Domingo Perón en 1955 y también como resultado de los coletazos de la Revolución Cubana (1959) y de los cambios generados por el Concilio Vaticano II, numerosos partidos y grupos políticos atravesaron profundos cambios, tanto en sus identidades e idearios como en sus programas (ALTAMIRANO, 1992). Uno de estos sujetos políticos que se vio afectado en este sentido por el proceso de transformaciones de la época fue el nacionalismo de derecha.

Éste, típicamente definido por la historiografía como autoritario, católico, corporativista, antiliberal, antiimperialista, anticomunista, revisionista, antisemita y violento, se caracterizó durante la década del sesenta por un acercamiento gradual a las masas políticas a partir de sus vínculos con el peronismo. Al mismo tiempo, la "nacionalización" generalizada de la política argentina urgió al nacionalismo de derecha a definir los límites de su identidad política (NAVARRO GERASSI, 1968; MCGEE DEUTSCH, 2005; LVOVICH, 2003, 2006; BUCHRUCKER, 1999; GALVÁN，2008，2012; SPEKTOROWSKI，1990; FINCHELSTEIN, 2002, 2008, 2010; DEVOTO, 2006; GOEBEL, 2011).

Esta serie de transformaciones y definiciones identitarias se pueden rastrar en el discurso gráfico de semanarios, boletines y panfletos nacionalistas del período. En ellos se observa un particular énfasis en las representaciones de figuras masculinas. Este recurso del estereotipo masculino fue uno de los elementos discursivos más típicos entre los nacionalistas de mediados de siglo y su utilización intentó apelar a viejas y nuevas tradiciones políticas y culturales con el fin de establecer claros límites identitarios y de redefinir su posición en el nuevo político.

En este sentido, con el objetivo de rastrear estos cambios, el presente artículo analiza el uso de determinados estereotipos masculinos en las publicaciones de dos representantes del nacionalismo de derechas de esos años: el grupo de intelectuales responsables por el 
semanario nacionalista $A z u l$ y Blanco $(A y B)$ y la agrupación política juvenil, Tacuara. Ambos casos de análisis fueron seleccionados no sólo por su carácter representativo del nacionalismo de derecha de esos años, sino también porque su signo novedoso ${ }^{\mathrm{i}}$ permitió plasmar los principales cambios que se produjeron entre los nacionalistas.

Efectivamente, tanto Tacuara como $A y B$ fueron producto del proceso de cambios políticos e ideológicos iniciados en Argentina a partir de 1955. El primero de ellos surgió de las reuniones de varios ex militantes de la Unión Nacionalista de Estudiantes Secundarios (UNES) y de la Alianza Libertadora Nacionalista (ALN), quienes decidieron formar una agrupación política adoptando el nombre que había pertenecido a una publicación de la vieja UNES y que mejor representaba sus influencias revisionistas ${ }^{\text {ii }}$. De este modo, el Movimiento Nacionalista Tacuara (MNT) comenzaría su militancia política en el marco de los conflictos motivados por la introducción, durante la presidencia de Arturo Frondizi, de la potestad de entregar títulos universitarios a instituciones privadas - conocidos como el enfrentamiento entre la universidad "Laica o Libre" „iii_ donde defenderían las posiciones de la educación católica.

El grupo de jóvenes católicos y de derecha, fundadores de Tacuara, era conocido por sus contemporáneos por protagonizar numerosos episodios de violencia política y por su iconografía y discurso antisemita, revisionista, antiliberal y anticomunista. Pese a estas características distintivas, Tacuara distaba de ser un grupo homogéneo. De hecho, poco tiempo después de su fundación, se separó en tres grupos, debido a profundas diferencias ideológicas que resultaron en la imposibilidad de continuar con un programa común. Con la llegada a este movimiento "aristocrático"iv de militantes con simpatías peronistas y con la declarada intención de la jefatura del MNT de acercarse al peronismo para cooptar sus bases sociales, la frágil trama ideológica que sustentaba sus prácticas de violencia política se iría rasgando al ritmo de los acontecimientos políticos nacionales e internacionales de la convulsionada década de los sesenta. Así, en 1960 se originó la Guardia Restauradora Nacionalista (GRN), un año más tarde el Movimiento Nueva Argentina (MNA) y en 1963, el Movimiento Nacionalista Revolucionario Tacuara (MNRT). La primera de estas subdivisiones respondió a una radicalización de las posturas ultra-derechistas y antisemitas; por su parte, el segundo grupo se originó a partir de las crecientes influencias peronistas 
dentro de Tacuara y, finalmente, el último grupo se formó por el crecimiento de tendencias izquierdistas dentro de un núcleo de militantes, influenciados por la Revolución Cubana.

Pese a las descollantes diferencias entre los sub-grupos Tacuara, las características más destacadas del primer MNT (antisemitismo, anticomunismo, revisionismo, entre otras) fueron las que predominaron en los discursos sociales de los contemporáneos, al momento de tipificar a todos estos grupos. Esto se debió también, muy probablemente, a la magnitud de los atentados antisemitas cometidos por el MNT y a la extravagancia de sus simbologías y rituales. Por estos motivos, se considera que las diferencias radicales entre estos grupos no solo no opacaron la subsistencia de elementos identitarios e ideológicos comunes (como por ejemplo el revisionismo o la defensa de la causa nacional), sino que, por el contrario, fueron prueba de la heterogeneidad de la ideología nacionalista en esos años.

Del mismo modo, el grupo de intelectuales en torno al semanario $A y B$, aun cuando más constante en sus adscripciones ideológicas y políticas debido a su mayor madurez política ${ }^{\mathrm{v}}$, también sufrió importantes resquebrajamientos y disidencias de sus integrantes a lo largo de sus diez años de vida. $A y B$ fue fundado durante la segunda presidencia de la autodenominada Revolución Libertadora por un grupo de reconocidos intelectuales y políticos nacionalistas de derecha (muchos de los cuales habían formado parte del gobierno del primer presidente posperonista, General Eduardo Lonardi) que, decepcionados frente al golpe palaciego por el que había subido a la Presidencia de la Nación el General Pedro Eugenio Aramburu, decidieron fundar un periódico político de frecuencia semanal.

El semanario formó parte así, desde 1956 a 1969, de una cultura gráfica (CHARTIER, 2007) signada por la explosión de nuevos semanarios políticos a partir de la caída del peronismo -muchos de ellos de carácter militante, pero no exclusivamente- que buscaban el reposicionamiento del grupo político-intelectual al que representaban en el nuevo campo de fuerzas político, tal como había quedado reconfigurado a partir la proscripción del peronismo (MELON PIRRO, 2002 y 2009, pp. 159-173; EHRLICH, 2011, pp. 14-31). En este marco, la publicación se caracterizó desde un primer momento por influir en la opinión pública a partir de un discurso eminentemente nacionalista-legalista que fue virando hacia posturas fuertemente corporativistas. A lo largo de esta trayectoria $A y B$ siempre conservó su lugar de centro aglutinador de ideas y de reconocidos intelectuales del nacionalismo de derecha ${ }^{\mathrm{vi}}$. Asimismo, habiendo basado su popularidad en una acérrima oposición a los gobiernos del 
momento, logró volverse representativo de un amplio sector de la opinión pública (su tirada máxima alcanzada llegó a 100.000 ejemplares). Efectivamente, no obstante su estilo elitista y pedagógico, esta página de opinión nacionalista logró alcanzar un público relativamente masivo durante sus años de existencia.

La popularidad que había ganado $A y B$ en sus primeros meses motivó al grupo a fundar un partido político del mismo nombre en el contexto de los debates por la convocatoria para formar la Convención Constituyente de 1957. Sin embargo, durante la presidencia de Arturo Frondizi, con sus fuerzas divididas y su popularidad en merma, el partido se disolvió y los "azulblanquistas" comenzaron a dar forma a un programa revolucionario, nacionalista y corporativista que recuperaba elementos del nacionalismo de 1930 y 1940 y que tenía el objetivo de volver a fundar las instituciones políticas del país. En esta misma línea, tras su primera clausura, el semanario reabrió sus puertas en 1961 con el sugestivo nombre de $2 d a$ República. Desde esta plataforma, luego de una breve interrupción debida otra vez a la censura (en agosto de1961), buscó el apoyo de trabajadores, sindicatos y militares -cada uno de estos sectores considerado indispensable- para realizar la "Revolución Nacional", la cual se planteaba como única salida a la crisis institucional, política y económica que, según su criterio, imperaba en el país desde la caída de Perón.

En 1963, el periódico fue cerrado por decreto presidencial y la voz de los "azulblanquistas" se mantuvo dispersa y débil a lo largo de la presidencia democrática de Arturo Illia. Luego de este impasse, $A y B$ regresó con el golpe del General Juan Carlos Onganía, autodenominado "Revolución Argentina". El nuevo y rejuvenecido equipo editorial a cargo del ya clásico semanario nacionalista retomó su crítica política con el nombre de $A z u l$ y Blanco. Para la Segunda República (en adelante AyBII), aunque esta vez con confianza en un gobierno que parecía encarnar sus expectativas revolucionarias. En efecto, a mediados de 1966 todo parecía indicar que, bajo el ala de Onganía, los objetivos de la revolución nacional, tantas veces enunciados por los "azulblanquistas", finalmente irían a cumplirse. Sin embargo, como ya les había ocurrido en otras oportunidades, el gobierno no tardó en decepcionarlos.

Así, frente al nuevo rumbo del gobierno, $A y B I I$ integró una vez más las filas de la prensa de oposición. Hasta el momento de su clausura final, en 1969, el semanario aprovechó este rol para la conformación de una nueva fuerza política, el Movimiento de la Revolución Nacional (MRN), que adoptó un carácter más marcadamente populista que la anterior 
incursión en la praxis política del grupo.

Esta larga trayectoria de $A y B$, al igual que la historia de Tacuara, constituyen el marco explicativo del uso de las imágenes masculinas en los nacionalistas de fines de 1950 y 1960. En este sentido, la materialidad del semanario nacionalista demuestra, al igual que los boletines de difusión de las agrupaciones Tacuara, un intento de auto-presentarse como actores políticos y culturales influyentes en su contexto, bajo el signo de determinado imaginario. En especial, en ambos casos -como se intenta mostrar en el presente artículo- se percibe una predominancia de estereotipos masculinos para definir la propia identidad y para delimitar un "otro" o adversario político.

De esta manera, se presentarán a continuación las razones por las cuales los estereotipos masculinos fueron utilizados con frecuencia por estos nacionalistas, a partir de objetivos claramente definidos. Seguidamente, se analizan las principales características de los estereotipos masculinos incluidos en las publicaciones en cuestión, tanto en vistas de las influencias ideológicas y culturales del nacionalismo de mediados de siglo, como en relación a sus objetivos políticos concretos en el contexto cambiante del posperonismo.

\section{Importancia de los estereotipos masculinos en las publicaciones del nacionalismo de derecha en la larga década del sesenta}

Pese a que las publicaciones de las agrupaciones Tacuara -Ofensiva, del MNT (1962), Tacuara. Vocero de la revolución nacionalista (1964) y Barricada, ambas del MNRT (1963) y Mazorca, de la GRN (1966, 1968-1969)- y el semanario $A y B$ en sus tres etapas $-A y B$ (de 1956 a 1960), 2da República (de 1961 a 1963) у AyBII (de 1966 a 1969)- difieren ampliamente en cuanto a su diagramación, objetivos y -principalmente- contratos de lectura y lectores modelos propuestos, todos ellos coinciden en la importancia de recurrir a imágenes (tanto figurativas como verbales) para facilitar el acceso y la comprensión dirigida de la información proporcionada a sus lectores. En este sentido, los estereotipos son el principal dispositivo homogeneizador de representaciones y, como tales, su uso es muy frecuente en $A y B$ y en los boletines de Tacuara. 
En particular, el semanario $A y B$ apuntó desde un comienzo a un lector opositor a las políticas del gobierno. Así, se preocupó por mostrar distancia del gobierno y una creciente intransigencia en la crítica a las políticas antipopulares y antinacionales de los presidentes $\mathrm{P}$. E. Aramburu y Arturo Frondizi. Basándose en una postura legalista, comenzó a interpelar a un público disconforme con las restricciones dictatoriales a la libertad, resaltando la ironía que derivaba del nombre que se había adjudicado a sí misma la dictadura de Aramburu. Desde este lugar, $A y B$ comenzó a ganar popularidad en sectores no exclusivamente nacionalistas.

Parte de este éxito no debe interpretarse sin tener en consideración ciertas condiciones materiales básicas que acompañaban al semanario desde su primer número. Entre éstas, se encuentran el acotado número de páginas que facilitaba una lectura medianamente rápida y completa de la revista. Asimismo, aun cuando $A y B$ se caracterizaba por ser una de las publicaciones más baratas del mercado editorial de la época (MELON PIRRO, 2002), el mismo ejemplar era leído por varias personas que compartían entre sí una única copia (AAVV, 1992). Esto último no sólo da cuenta de un número real de lectores que supera al número de tirada, sino que también ilumina las implicancias culturales de la lectura de $A y B$. Es decir, las características de esta lectura colectiva (normalmente llevada a cabo en fábricas o sindicatos) sugieren una distribución y discusión mayor de las temáticas propuestas por el semanario cada semana.

La diagramación de la primera página del semanario resaltaba, principalmente, la nota política más importante de la semana (junto a la opinión de la redacción al respecto) y una caricatura política (cuya importancia superaba la del logo). En los números que incluían un diseño de tapa de estas características -que si bien no eran todos, si eran la mayor parte de ellos- el estilo sobrio del logo quedaba opacado por la inclusión de la viñeta de humor gráfico, que generalmente ocupaba un cuarto de página o más. La viñeta de humor siempre se relacionaba directamente con la nota principal, satirizando su temática. De esta manera, la caricatura política representaba un vehículo masivo de difusión de los posicionamientos políticos del semanario, que debido a su estructura cómica escapaba con facilidad a las redes de la censura de este período. Con estas herramientas, la caricatura política tenía la capacidad de proponer una crítica más abierta, que motivase al lector a cuestionarse lo obvio y a desmontar la realidad. Asimismo, el recurso figurativo combinado con el humorístico y un lenguaje simple, llegaban a un público masivo y no necesariamente erudito pero sí 
debidamente informado (DO NASCIMENTO, 2003). En este sentido, las viñetas de humor de $A y B$ reflejaban de manera sintética e incisiva el contenido de la nota de tapa, cuya comprensión quedaba a disposición de una lectura más rápida, con menos requisitos de concentración.

Así, la relación texto-imagen ${ }^{\text {vii }}$ que construyó el semanario se caracterizó por una relación de equilibrada complementariedad. Más allá de la importancia que se le otorgaba a la función del caricaturista desde el equipo editorial ${ }^{\text {viii }}$, las imágenes cumplían una importante función explicativa de los contenidos del número, que eran condensados bajo formas retóricas típicas del humor gráfico (ironía, hipérbole, metáfora, etc.), para volver más accesible su comprensión al lector. En ellas, siempre había retratada al menos una figura masculina cuyos atributos -como se explicará más abajo- tenían por objetivo denostar la figura presidencial, como forma de mostrar oposición a las políticas del gobierno nacional (el caso paradigmático de este uso del estereotipo fue la representación de Arturo Frondizi).

En consonancia con este objetivo de "simplificar" la información para el lector, la esquematización de las secciones de $A y B$, más allá de la columna editorial, explicitaban una forma sencilla y rápida de encontrar la información que el lector pudiese llegar a considerar relevante, según sus intereses ${ }^{\text {ix }}$. Relacionada con esta orientación aparentemente más popular de la revista que se describió hasta el momento, se deben confrontar ciertas características de su materialidad y estrategias que relativizan esta cuestión, como por ejemplo el uso frecuente de recursos tales como la ironía, los dobles sentidos, las personificaciones, las sinécdoques, metonimias, metáforas, los juegos de palabras en el humor gráfico, en titulares y en el cuerpo de los artículos, así como también las frases en idiomas extranjeros y numerosas referencias literarias. Estas estrategias retóricas apelaban a un lector con un conocimiento enciclopédico vasto que le permitiese completar el sentido del texto de $A y B$. Esto se ve reforzado a través de las implicancias del formato de hoja-sábana (de lectura más pausada y que remite a un lector más tradicional) y del estilo erudito de escritura ya mencionado.

Por otra parte, la inclusión de eslóganes en los pies de página, la presencia de las secciones más cortas que resumían o comentaban las notas largas de opinión, el asiduo uso del imperativo, de la primera persona, de preguntas retóricas y de exhortaciones directas al lector, como así también las frases impersonales, libres de ambigüedades y no modalizadas daban cuenta de un enunciador objetivista y autoritario y de corte pedagógico, que pretendía 
legitimar sus afirmaciones tras un "discurso verdadero".

También, es necesario tener en cuenta que la descripción de las carátulas o primeras páginas de una publicación son su "carta de presentación". Es decir, éstas ya no sólo "presentan" el contenido de la revista o semanario sino que "representan" su línea editorial; son su "marca registrada". En calidad de esto, las tapas encierran tanto las formas de presentación gráficas como los padrones de diagramación adoptados que pasan a ser reconocidos por el público lector (STEIMBERG, 1997; DO NASCIMENTO, 2003). Teniendo en cuenta eso, $A y B$ formulaba un lector modelo específico ya desde la portada. Estas estrategias excluían a quien no estuviese embebido de la situación política nacional y a quien no contase con las destrezas necesarias para saber interpretar el lenguaje figurado de los titulares y las viñetas de humor.

En resumen, en base a las características mencionadas, el lector modelo de $A y B$ era un lector maduro, con capacidad para interpretar los juegos de doble sentido y de reconocer en el lenguaje figurado los contenidos presentados (la información extralingüística); es decir que se trataba de un público culto e informado de la actualidad política nacional que encontró en esta publicación manifiestamente nacionalista un refugio interesante en un contexto de represión política y censura mediática. Esto último, a su vez, no es un dato menor. En efecto, la revista, en este marco de opresión y represión generalizada, tuvo una particular influencia en los sectores peronistas, que pudieron canalizar a través de ella sus reclamos políticos ${ }^{\mathrm{x}}$. En este marco, la hoja nacionalista se ponía a disposición del lector peronista desde una retórica claramente representativa del discurso nacionalista. Como tal, pretendió "iluminar" al actor político peronista en la "vía nacional"; es decir, demostrarle al lector (visto como actor político) que sus reclamos hallaban solución en la "causa nacional".

La influencia del peronismo en el semanario -que, a pesar de haber sido en un comienzo antiperonista, aceptaba y compartía las ideas, valores y tradiciones del movimiento peronista (GALVÁN, 2011a)- también alcanzó a las representaciones de figuras masculinas. En este sentido, las representaciones de Perón en un comienzo eran más bien abstractas (se utilizaban referentes como "el gobierno anterior", "el líder proscripto", etc.). Pese a ello, se colaba en el discurso "azulblanquista" una imagen fuerte y viril de Perón que contrastaba con el débil y estéril intento de Aramburu de dominar la situación política ( $A y B$, nros. 34, 06/02/57; 52, 11/06/57; 53, 18/06/57; 75, 19/11/57). Así también, por ejemplo, en la nota 
titulada "Afeminamiento de la política" se criticaba el contexto de caos político del segundo gobierno de la "Libertadora" y se lo contrastaba con el "exceso de dominación viril" del gobierno peronista:

Es ley histórica que después de un exceso de virilismo en el que el domador abusa de sus condiciones, de 'macho' sobre la masa 'hembra', sobrevenga una rebelión de la emotividad al momento político argentino en carácter marcadamente femenino y, por lo mismo, confuso y peligroso. ( $A y B$, nro. 5 , 04/07/56).

De esta manera, se asociaba a Perón el estereotipo de líder viril y dominante que es como se analiza con mayor detalle en el apartado siguiente- tan caro a la tradición nacionalista argentina. Pero Perón no fue la única figura masculina tematizada por el semanario en esta primera etapa. Más allá del general Lonardi, retratado siempre como el ícono del líder militar honorable ( $A y B$, nros. 4, 27/06/56; entre otros), el presidente Arturo Frondizi -como se sugirió más arriba- fue el blanco predilecto en el que $A y B$ concentró su manejo de los estereotipos.

En el marco del avance de los beneficios a capitales extranjeros ni bien asumiera Frondizi, el semanario reconocía como enemigos del interés nacional tanto a estas entidades como a la izquierda marxista y ambos polos se combinaron en las nuevas representaciones de Arturo Frondizi después de su "gran cambio" (GALVÁN, 2012, pp. 121-172). Desde la campaña presidencial que había comenzado a fines de 1957, pero principalmente a partir del triunfo de Arturo Frondizi en febrero de 1958 hasta la censura y cierre por decreto presidencial de esta primera etapa de $A y B$ a fines de 1960, la figura del presidente fue objeto de variadas e ingeniosas caracterizaciones -tanto en el discurso gráfico como en el verbalque describen una trayectoria en la cual de ser el representante legítimo del pueblo, pasa en pocos meses a ser considerado un agente enemigo, infiltrado en el seno mismo del gobierno. El declive político, moral y legal de la figura de Frondizi según el testimonio del semanario nacionalista no sólo se lee en los tópicos temáticos noticeables a los que se abocó el equipo de $A y B$ durante la presidencia ucrista, sino que también se deducen de las estrategias retóricas y opciones léxicas puestas en práctica por la discursividad de esta publicación (GALVÁN, 2011b, pp. 14-18).

En este sentido, la selección temática que realizaba $A y B$ al momento de referirse al 
gobierno de Frondizi se encontraba relativamente limitada por el subgénero (periodismo político de opinión), razón por la cual los tópicos que los redactores "azulblanquistas" consideraron noticeables no diferían en gran medida del resto de las publicaciones de la época que también destacaban la firma de los contratos petroleros y sus consecuencias, los debates de la "Laica o Libre", el pacto con Perón y la relación con los sindicatos, el antisemitismo y el caso Eichmann, el plan CONINTES ${ }^{\mathrm{xi}}$, la Revolución Cubana, la relación con las Fuerzas Armadas, entre otros (TERÁN, 1993; SIGAL, 2002; CANDIANO, 2009; SPINELLI, 2007; EHRLICH, 2010; GALVÁN, 2008). Sin embargo, sí resulta distintivo de esta publicación el énfasis puesto en las noticias sobre la relación del presidente con las Fuerzas Armadas, el antisemitismo y la suerte de "cruzada" que se puso en marcha contra el comunismo supuestamente arraigado en el seno mismo del gobierno ${ }^{x i i}$.

Hacia fines de 1960, cuando el partido Azul y Blanco fracasó y la creciente oposición a las políticas "antinacionales" de Frondizi, empujaron al grupo hacia posturas golpistas, recobró fuerza la idea de la "Revolución Nacional", para cuyos fines los trabajadores politizados y "concientizados de la importancia de defender el interés nacional" se constituyeron en el elemento fundamental del programa corporativista. En esta misión se concentró, en particular, 2da República.

Cuando $A y B$ fue clausurada por primera vez, a fines de 1960, se retomaron las ediciones bajo un nuevo formato y con un nuevo título que llevaba implícita esta radicalización de las posturas corporativistas en el grupo. En efecto, la fundación de una "segunda república" sobre las ruinas de la primera (liberal, extranjerizante e ineficiente) era el objetivo final de la Revolución Nacional. El lector modelo del nuevo formato ya dejó de ser una entidad discursiva abstracta e ideal y se identificó concretamente con el trabajador politizado, el trabajador peronista o el sindicalista. El enunciador adoptó así en estos casos el rol de un líder político que dictaba a sus seguidores el curso de acción y exigía demandas en su nombre ${ }^{\text {xiii }}$. En otras ocasiones, el enunciador se alejó del papel de líder y, a través del uso de la primera persona, en conjunción con el recurso de la ficción, se ponía en la piel del "hombre simple" que relataba, desde su experiencia "personal", los problemas del trabajador común ${ }^{\text {xiv }}$.

Pero esta suerte de manifiesto largo que fue, desde lo discursivo, 2da República tuvo un abrupto final en 1963 y el posterior silencio de $A y B$ como grupo (muchos de sus integrantes continuaron escribiendo de forma independiente) duró tres años. En el transcurso de este 
tiempo, los cambios del escenario político definieron un retorno de la publicación desde un lugar enunciativo muy diferente.

Con el golpe de 1966, autoproclamado "Revolución Argentina", se reeditó el semanario con su nombre original, al que se le agregó el subtítulo Para la Segunda República. A través de esta combinación, se volvía a la idea primera del semanario pero recuperando la experiencia de los 53 números de $2 d a$ República. El nuevo semanario no sólo había rejuvenecido su equipo editorial, sino que había reformulado también su diseño, formato, tamaño, relación imagen-texto, secciones y calidad de página. El nuevo enunciador "azulblanquista" buscaba evocar en el lector las mismas representaciones que le habían suscitado la primera versión de la revista, pretendiendo de esta manera que el lector los percibiese como continuadores de su papel de guardián crítico del interés nacional. Pero este intento explícito de generar ese efecto de "continuación" marca, precisamente, la distancia real (que era necesario soslayar a partir de estas estrategias) entre la primera y la segunda generación de "azulblanquistas".

La nueva $A y B I I$, pretendidamente continuadora de aquella revista inaugurada en 1956, era una publicación típicamente "moderna". Con una tirada máxima de 30.000 ejemplares, la renovada publicación pretendía, desde la tapa, cautivar a un lector más joven con fotos a color y collages muy sofisticados que abarcaban la superficie completa de la página. La relación imagen-texto estuvo durante los dos primeros años al borde del desbalance en favor de la primera. En este sentido, en casi todas las páginas había alguna fotografía, caricatura política o dibujo ilustrativo y muchas veces había tan sólo imágenes en páginas completas. Asimismo, la diagramación de página, la alta calidad del papel, el número de páginas totales (entre dieciséis y veinticuatro) y la inversión en la parte artística dan cuenta de una complejidad y sofisticación mucho mayor que se explica por una red de financiamiento más vasta ${ }^{\mathrm{xv}}$.

Estas diferencias con la primera etapa ${ }^{\mathrm{xvi}}$ van en el sentido de una lectura más fácil y atractiva. No por ello, sin embargo, el lector modelo de esta etapa puede considerarse menos culto ni menos reflexivo que el anterior ${ }^{\text {xvii }}$. Asimismo, la multiplicidad de notas conllevaba el tratamiento de diversas temáticas, no necesariamente relacionadas entre sí, en un mismo número. Esto suponía un rastrillaje más amplio de la actualidad que ahora incluía aspectos novedosos en comparación con la versión clásica del semanario, como la actualidad y crítica de la alta cultura y el deporte, la encuesta de opinión como prueba de verdad, los relatos 
criollistas (tanto verbales como iconográficos) y la historia del pensamiento nacionalista. Además de eso, la sección internacional tenía más relevancia, había más viñetas de humor gráfico y se respondía con un breve comentario cada carta de lector publicada. Estas características del nuevo contrato de lectura propuesto parecen indicar no sólo la inclusión de los intereses ampliados del lector -lo que, a su vez, al delimitarlos, acotaba la extracción demográfica del lector modelo ya no principalmente definido en base a sus opiniones políticas-, sino también la intención de ampliar el mercado hacia lectores más jóvenes e inquietos, que se sintiesen interpelados por las referencias culturales (ya no sólo implícitas como en la primera etapa).

En este marco la figura masculina positiva predominante era la de Onganía. En un comienzo, con el objetivo de apoyar el nuevo gobierno de facto autodenominado "Revolución Argentina", se exaltó la figura del General golpista Juan Carlos Onganía. Este presidente de facto había sido visto al principio por la publicación como el jefe militar, católico, idealista, pero a la vez, eminentemente "un hombre de acción", capaz llevar a cabo las reformas estructurales necesarias para sacar al país de la crisis (GALVÁN, 2012, p. 262). Sin embargo, tras pocos números desde su reinauguración, la revista comenzó a criticar fuertemente su gobierno y a comienzos de 1967 se pasó a la oposición. Estas circunstancias del contexto paratextual repercutieron en la materialidad del semanario, que cambió su director ${ }^{x v i i}$ y se acercó paulatinamente a las nuevas directivas sociales de la encíclica papal Populorum Progressio $^{\mathrm{xix}}$ y a algunos movimientos latinoamericanistas (como la revolución nacional peruana de 1968). Con este cambio sobrevinieron importantes modificaciones en el formato que trajeron una absoluta primacía de la palabra por sobre la imagen y se dejó de lado el lenguaje figurado en el cuerpo de las notas. La lectura se facilitaba por el nuevo formato de medio-tabloide que adoptó la publicación, pero el tiempo de lectura se incrementó y se obstaculizó la búsqueda rápida de información, debido a que con la mayor superficie de texto, disminuyó la superficie dedicada a los separadores (tanto figurativos como verbales), a los titulares grandes, a los encabezados y a los comentarios, concentrando la atención del lector en las notas políticas y doctrinarias.

Por otro lado, si bien el número de páginas se mantuvo, se volvió a un papel más económico y se reemplazaron las imprentas privadas con las que se había trabajado anteriormente por la Cooperativa Obrera Gráfica Talleres Argentina Limitada (COGTAL), 
cuyo presidente era el líder sindicalista de izquierda, Raimundo Ongaro (Entrevista A.M., 19/01/12). En este último punto se puede observar cómo el estrechamiento de las redes de sociabilidad (con el consecuente influjo ideológico que representaba la amistad de los "azulblanquistas" con Ongaro, quien encabezaba la central de trabajadores disidente, CGT de los Argentinos) dejó una huella importante en la materialidad de la revista, por lo que terminaría afectando al contrato de lectura de manera irreversible, como se observa en los últimos números.

Éstos se caracterizaron por una invitación abierta a todos los sectores partidarios, a los militantes de base y al pueblo, en general, a unírseles en un curso de acción único de resistencia a la dictadura a través de su propuesta de transformación corporativista, autodenominada "Revolución Nacional". En este sentido, los "azulblanquistas" reformularon su clásica propuesta corporativista, incorporando el eco de las temáticas de la hora; es decir, desde una posición progresista y cercana a los sectores populares. En este marco, hace pie en la publicación una nueva figura masculina positiva, diferente de los laureados líderes militares que ocupaban ese lugar hasta el momento. Así, se introdujo en este lugar de admiración de una nueva figura masculina heroica, cuya expresión máxima fueron los líderes políticos izquierdistas Raimundo Ongaro y Ernesto "Che" Guevara. Para el semanario, el valor del militante convencido de sus ideales ( $\sin$ importar del todo su ideología) era uno de los factores fundamentales en la ecuación revolucionaria. En este sentido, al conocerse la muerte del "Che" Guevara, $A y B$ le dedicó una sentida editorial para homenajearlo y recordar su heroicidad, más allá de sus ideas distorsionadas por el retraso argentino:

(...)sólo la defección de la Argentina, de su Revolución postergada y traicionada cien veces, puede explicar el auge de la violencia marxista en una América desgarrada por la entrega, el atraso y el privilegio. Mientras la Argentina no eleve y luche por sus banderas de soberanía, desarrollo y justicia, muchos argentinos bien nacidos - como Ernesto Guevara- seguirán peleando y muriendo por banderas extranjeras (AyBII, nro. 57, p. 3, 16/10/67).

De modo similar, Ongaro proporcionaba un molde actualizado a la época de la figura del militante nacionalista ideal. Este vínculo con Ongaro se relacionaba con la voluntad corporativista de $A y B I I$ de acercarse a la política sindical. En este sentido, la atención de los 
redactores hizo foco en la carrera de este dirigente en ascenso, a quien presentaban ante sus lectores como el portador de un "nuevo sindicalismo", serio, comprometido con su causa, no violento, consecuente con sus ideas y profundamente devoto, capaz - esta vez, sí- de llevar a cabo la Revolución Nacional (AyBII, nros. 56, p. 21, 09/10/67; 58, pp. 19-20, 23/10/67; 76, pp. 14-15, 03/09/68).

En conjunto, todos estos cambios finales indican el cierre de un nuevo pacto de lectura, diferente a los anteriores. Ahora se apuntaba al lector militante (de cualquier adscripción ideológica pero dispuesto a defender el interés nacional) y se buscaba prepararlo para una acción política conjunta. Para ello, la figura del militante idealista, comprometido y con voluntad de mártir ofrecía el reflejo perfecto con el que debía identificarse el lector modelo. De esta manera, el público de esta etapa ya no era el ciudadano bien informado, disconforme con el gobierno y susceptible de transformarse en un sujeto político concreto, ni el peronista que debía ser concientizado en la causa nacional-corporativista. El lector modelo de los últimos meses de $A y B I I$ era un sujeto político preexistente al que se buscaba convencer de unírseles en la lucha contra un enemigo común. La radicalidad de esta propuesta, como era esperable, no tardó en ser cercenada por la dictadura, que decretó la muerte definitiva del semanario en julio de 1969.

A diferencia de $A y B$, en los boletines de los grupos Tacuara $^{\mathrm{xx}}$ el lector modelo es el joven con inquietudes políticas, que el editor de la publicación intentará educar desde cero, en un marco ideológico afín. Las marcas más distintivas que definen el lector modelo de las publicaciones tacuaristas fueron el uso del término común "camarada", a veces combinado con las denominaciones "camarada nacionalista", "camaradas estudiantes", "joven nacionalista”, “compatriota” o "joven argentino”, el estilo historietístico de las imágenes, los guiños en texto e imágenes al género de aventura de la literatura juvenil, los enunciados que "educaban" a un lector desinformado completamente y "orientaban" su opinión política en un sentido definido y la interpelación directa a la acción concreta e inmediata (apelando al estilo confrontativo y pragmático que definió desde el principio a los militantes de esas organizaciones). Complementariamente, estos boletines recurrían a comentarios explícitamente antisemitas, anticomunistas, revisionistas y antiliberales. Con ellos, se delimitaba a un público acotado que compartía esas creencias.

En el discurso de estos órganos de difusión predominaba un enunciador pedagógico que 
pretendía ser objetivo, a la vez que buscaba establecer una relación de complicidad con su lector (GALVÁN, 2010). En este contexto discursivo, la iconografía tuvo un rol preponderante. Las imágenes de las publicaciones tacuaristas remitían a los fascismos europeos, al revisionismo, al antisemitismo, al anticomunismo así como a la tradición católica, a través de la repetición de motivos y modos de organización de las figuras, por lo que requerían de un lector que conociese de antemano y coincidiese con estas ideas para poder ser interpretadas y generar el efecto buscado por el enunciador en su público lector. Así, el conocimiento básico exigido a los lectores de los boletines desde la diagramación, tapas y titulares servía de precondición para participar de un debate acerca de la actualidad política nacional, sostenido ya desde el cuerpo textual de las revistas.

En general, en el marco de este debate, los postulados de los fascismos europeos y del revisionismo nutrían el propio programa político de las agrupaciones, y las experiencias históricas de estos fungían como parámetros de comparación y modelos a imitar. Los marcos interpretativos proporcionados por estas ideologías se conjugaban en los boletines de Tacuara con el misticismo católico y la admiración de figuras heroicas, propias de la edad de los integrantes de Tacuara (entre 14 y 25 años de edad) (ORLANDINI, 2008, pp. 195-196; GALVÁN, 2008, pp. 53-54), para darle forma a héroes propios, cuya virilidad e hidalguía los enaltecía, ante los ojos de los tacuaristas. Como se verá más abajo, de estas referencias emergerán héroes-mártires propios que se constituirán en banderas de la causa nacional (el principal de ellos es el joven caído el 17 de octubre de 1945 Darwin Passaponti). Asimismo habiendo sido martirizados en la lucha por la Patria, estos héroes reunían las condiciones necesarias para erigirse como el ideal de hombre que motivaba en la lucha a estos jóvenes y los llevaba a identificarse con los valores que representaba.

En síntesis, aun cuando el lector modelo de $A y B$ era, en un primer momento, un lector maduro e informado, sin una identidad política específica y en los últimos años este se fue definiendo en un sentido político concreto, mientras que, por otro lado, el lector de los boletines de las agrupaciones Tacuara era el joven militante nacionalista que se iniciaba en la vida política y que por ese motivo aun requería un adoctrinamiento más directo, en ambos casos se recurrió a estereotipos masculinos y se les otorgó un papel central en su discurso. Éste consistía, principalmente, en lograr la cohesión e identificación de los lectores con las publicaciones, en base a las premisas propuestas por los redactores y con ello -como se 
describe con mayor detalle en el próximo apartado- se buscaba definir una identidad política propia homogénea y un contrincante político claro; es decir, se pretendía, en última instancia, delimitar el espacio de acción política para los nuevos militantes nacionalistas y sus posibles aliados.

\section{Atributos del ideal de hombre nacionalista y de su antítesis}

La imagen estereotipada tiene la función, en general, de unificar y uniformizar las representaciones para un grupo determinado (MOSSE, 1996). En el caso de los nacionalistas argentinos de la segunda mitad del siglo veinte, como muestran las publicaciones de Tacuara y $A y B$, las imágenes masculinas fueron recuperadas con objetivos educativos y movilizadores. En el contexto de resquebrajamiento de las identidades políticas de esa época, que afectó al nacionalismo a partir de una creciente influencia de sectores peronistas en sus agrupaciones y de las nuevas ideas que trajeron la Revolución Cubana y la encíclica Populorum Progressio, éste apeló, por un lado, a figuras heroicas y viriles para establecer lazos identitarios comunes entre los lectores de sus publicaciones y, por otro, a la antítesis de esta imagen ideal de hombre, para definir a sus enemigos y para explicitar las características repudiables en un nacionalista.

Así, como se mencionó en el apartado anterior, $A y B I I$ incorporó en imágenes y textos el imaginario criollista (principalmente en la sección denominada "La página de Marenco") caracaterístico del revisionismo histórico con la intención de revalorizar los antecedentes culturales y políticos de la "lucha nacional". En este contexto, la figura del gaucho en actitud corporal proactiva (Fig. 1), a veces sufrido, con mirada adusta pero llena de dignidad (Fig. 2) se volvió un elemento central al combinar dos Pathosformeln ${ }^{x x i}$ clásicas: la del luchador $^{x x i i}$ y la del sufriente ${ }^{x x i i i}$. En los boletines de Tacuara también se invocó la iconografía criollista con el objetivo de establecer una línea de continuidad entre la lucha del gaucho del siglo diecinueve y la propia. Complementariamente, también se utilizó la imagen y la historia del joven Darwin Passaponti para construir un estereotipo del militante ideal más cercano. Darwin Passaponti fue un joven militante de la UNES (antecesora del MNT) que murió durante la manifestación fundacional del peronismo del 17 de octubre de 1945. El MNT lo 
reivindicó como su primer caído y uno de los requisitos para ingresar a la agrupación consistía en prestar juramento frente a su tumba en el cementerio de la Chacarita, en Buenos Aires. El carácter de mártir de Passaponti se complementaba así con este ritual de iniciación (Fondo CEN, caja 1424). La mística que generaba este héroe de la lucha nacionalista trascendió a las agrupaciones Tacuara. En ese sentido, también fue recuperado por $A y B$, como modo de mostrar continuidad entre la lucha nacionalista y los intereses peronistas $(A y B$, nro. $185,29 / 12 / 59)$.

La añoranza de las figuras heroicas y de épocas pasadas en el imaginario nacionalistaevidente tanto en el folclorismo como en la acérrima adscripción al revisionismo históricose condecía también con ciertos mecanismos de mitificación donde resonaban los ecos de los viejos fascismos europeos. En este sentido, Tacuara se rodeó de simbologías y rituales similares a aquellos del fascismo italiano y del nazismo alemán (el saludo romano, la sanción que implicaba tomar aceite de ricino, el uso de la cruz esvástica en atentados antisemitas como método intimidatorio, el uso de uniformes en actos públicos, desfiles, campamentos de

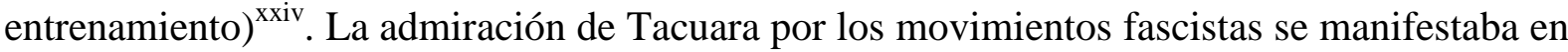
referencias en el cuerpo de los textos de las publicaciones y en la manifiesta admiración por determinados personajes masculinos de la historia. En este sentido, las publicaciones tacuaristas rendían homenaje en sus páginas a los "héroes" de Nüremberg, a Adolfo Hitler, Cornelio Codreanu, José Antonio Primo de Rivera y Benito Mussolini ${ }^{\mathrm{xxv}}$. Es que, en efecto, muchos tacuaristas admiraban profundamente el desempeño de Alemania e Italia durante la guerra y consideraban a estos líderes fascistas como héroes nacionalistas que dieron todo por su patria. Pero la influencia de los fascismos en Tacuara no se limitó simplemente a la imitación por admiración.

Tanto el fascismo como el revisionismo histórico y el criollismo proporcionaban a estas agrupaciones juveniles un marco romántico de referencia, un pasado que ellos consideraban mítico y en el cual se apoyaban como motivación y legitimación para su lucha en el presente. Así, al igual que los fascismos europeos, Tacuara retomó tradiciones dominantes en las sociedades de su época y con ellas dio forma a una liturgia y a símbolos que sirvieron de medio para fortalecer su identidades y difundir su mensaje político. En este proceso tuvo gran importancia la belleza del cuerpo masculino clásico.

Al igual que en el caso de los nacionalismos europeos (MOSSE, 1996; ADAM, 1992), 
el ideal masculino de Tacuara representaba virilidad, control, disciplina y dinamismo revolucionario. Pero el nacionalismo argentino de los sesenta tiene un antecedente más directo en los nacionalistas argentinos de la década del treinta. Según el trabajo de Federico Finchelstein (2002), los nacionalistas argentinos de 1930 presentaron la figura masculina del General golpista Uriburu como "el fenotipo de un 'nuevo hombre', que era una proyección de un ideal de belleza masculina previamente definido y ampliamente compartido" (FINCHELSTEIN, 2002, p. 114). En el caso específico de Tacuara, esta idea de un hombre nuevo sugerida por un héroe que se ajustase al ideal de virilidad, y sobre quien proyectar las expectativas de éxito del movimiento, se encontraba encarnada en la figura de Darwin Passaponti.

Particularmente para los integrantes del MNT y de la GRN, Passaponti representaba el ideal de virilidad, coraje e hidalguía al que ellos aspiraban con su militancia, a la vez que era depositario de las expectativas de éxito del movimiento. Como muestra la figura 3 , los rasgos de seriedad y austeridad que caracterizan al retrato del héroe al que Tacuara veneraba, indicados a través de los trazos duros, el ceño fruncido, la boca apretada y la mirada hacia un horizonte relativamente cercano, no se contraponen a las virtudes propias de la juventud, tales como la rebeldía y la libertad, representadas con el cuello de la camisa desabrochado y el mechón de pelo que cae sobre su frente. A su vez, los laureles que enmarcaban su rostro, a modo de fondo, sugieren la idea de triunfo, de victoria. Este rostro idealizado inundó las publicaciones de todas las agrupaciones Tacuara y su historia sirvió como modelo de lucha y sacrificio para los militantes nacionalistas que aun tenían en sus bibliotecas los libros de aventuras de Joseph Conrad y de Emilio Salgari. Esta predisposición a los escenarios heroicos servía, en este sentido, tanto para amalgamar la identidad militante como para legitimar el supuesto "rol histórico" que descansaba en los hombros de Tacuara (GALVÁN, 2008).

La insistencia en el carácter de mártir (de la revolución, de la causa nacionalista), el simbolismo y lo mítico alrededor de su muerte, de su tumba y de su imagen parecen sugerir un cierto goce. Efectivamente, el culto al héroe-mártir Passaponti se encuentra ligado al llamado "culto al soldado caído", que ha sido analizado por Mosse en relación con el uso de los cementerios y monumentos a los soldados caídos en las guerras de liberación contra Napoleón y en la Primera Guerra Mundial en Alemania, y con el modo en que sus connotaciones y repercusiones en la vida cotidiana han sido utilizadas por el nazismo 
(MOSSE, 1979). El autor sostiene que el culto al caído representa lo excepcional, la salida de lo cotidiano, dada por la búsqueda de ese "algo" supremo que justifica la muerte del héroe; ser atemporal y eterno, cuya adoración enfatiza la oposición y el rechazo a la modernidad en general. El mártir también simboliza el ritmo sostenido por la oposición vida-muerte (topos de la resurrección, tomado de la tradición cristiana). Como sostiene Mosse, el culto al caído recupera el continuo pasión-muerte-resurrección que en la Europa moderna de la preguerra es aplicado a la resurrección de la Patria, de la Nación. Al respecto, se podría citar un titular encontrado en Barricada que parece inspirado en estas afirmaciones: "Los que murieron para que la patria viva" (Barricada, No. 9, p. 4, s/f). Esta idea, a su vez, se materializa en los rituales alrededor de los monumentos al caído o de su tumba. Con esto se corresponden los actos que los miembros de Tacuara realizaban periódicamente alrededor de la tumba de su mártir, ya que, como menciona Mosse, la tumba del soldado caído no sólo es el lugar de veneración por excelencia, sino que representa el indicador del camino a seguir por la "futura raza de héroes".

La importancia de la resurrección del militante a partir de la muerte del héroe, es decir, el refortalecimiento del ímpetu de lucha, no se agotaba en el culto a Passaponti. En la galería de héroes, donde Passaponti ocupaba un lugar privilegiado, también se encontraban los "muertos de Cerveceros" (ver, por ejemplo, Tacuara. Vocero de la revolución, agostoseptiembre de 1964, p. 3). Los militantes del MNT y del peronismo caídos en el enfrentamiento entre militantes del MNT y comunistas del Salón de Cerveceros en Rosario en 1964 eran rememorados en las publicaciones del MNT y de la GRN periódicamente, y se celebraban misas en su memoria (ORLANDINI, 2008).

Asimismo, la moneda común para los nacionalistas de estos años del criollismo, repercutió en las imágenes masculinas de los héroes-mártires tacuaristas en el hecho de que la figura del gaucho del siglo diecinueve pasó también a ser un ícono de redención, a partir de su trágica sentencia de muerte firmada con el triunfo del imaginario liberal, cuyo mayor exponente había sido la narrativa sarmientina. En esta línea, al igual que AyBII, Tacuara también apeló a iconografías de gauchos que se valían de las Pathosformel del luchador y del sufriente. La conjunción de ambas sintetizaban una imagen de héroe masculino fuerte, viril, dedicado a su causa y sacrificado por ella por un acto de injusticia (GALVÁN, 2008, pp. 7778). Este tipo de veneración que provocaba el culto al mártir caído en la lucha por los mismos 
ideales que movilizaban a los militantes tacuaristas se caracterizaba, también, por la exaltación de los valores de la juventud y la camaradería, valores estrechamente relacionados, en la construcción del mito, con la perspectiva de triunfo (MOSSE, 1979) y que también habían sido adoptados por la iconografía nazi (ADAM, 1992). También la exaltación de la juventud de la figura de los caídos estaba asociada con la valoración de la virilidad y la belleza física masculina. De esto, las publicaciones aportan varios ejemplos figurativos que recuerdan a las figuras de los héroes del trabajo y al prototipo de hombre del arte de propaganda nazi. También en el cuerpo de los textos se leen frases como "en lugar de tanto palabrerío democrático y tanta imbecilidad liberal, hace falta la mano fuerte de un hombre macho, de un caudillo criollo para conducir los destinos de esta nación que está dejando de serlo" (Ofensiva, No. 11, p. 11, s/f).

Según Mosse, la belleza del cuerpo masculino representa tanto el autocontrol como la virilidad, metáforas, en última instancia, del respeto por la tradición y por una dinámica revolucionaria, a la vez. Igualmente, sostiene que el culto a la belleza física masculina (que, no hay que olvidar, presenta siempre una masculinidad agresiva), propio de los movimientos fascistas (encarnado en el "hombre nuevo" del fascismo italiano o del prototipo ario), no ha sido inventado por estos. El ideal, que remite claramente a la Pathosformel del atleta, tenía sus antecedentes inmediatos en los tipos ideales del caballero inglés o del American boy. Pero, en realidad, este ideal de belleza masculina se manifiesta por primera vez con el auge de la moral burguesa en el siglo dieciocho (MOSSE, 1996). También Marcela Gené (2005) incorpora a esta serie los ejemplos del héroe del trabajo comunista y del descamisado peronista. Del mismo modo, podría decirse que este ideal tampoco murió con el fin de la primera mitad del siglo veinte, y un claro ejemplo de ello es el prototipo del militante tacuarista, con su pelo corto y engominado y su uniforme de camisas pardas; estilo tan admirado (e imitado) a la salida de los colegios por los adolescentes de la época (Entrevistas a Yáñez de Gomera y a Emilio di Roccabruna, 18-04-2007 y 28-02-2007).

Pero el uso de los estereotipos masculinos, no sólo apelaba a reforzar las identidades y solidaridades de militancia y de origen, sino que también a través de el se buscaba motivar la acción política ya sea a partir de modelos heroicos a imitar, ya sea a partir de "males" a enfrentar y combatir.

En este último caso, se utilizaban imágenes teratológicas y estereotipos de "desviados" 
sociales para delimitar un enemigo cada vez más difuso. Como se explicó más arriba, este fue particularmente el caso del presidente Arturo Frondizi, cuya candidatura presidencial había sido leída por $A y B$ como una solución a la ilegitimidad del gobierno de facto de Aramburu, pero poco tiempo después de asumir la presidencia fue acusado de traicionar su plataforma electoral y de pactar con poderes extranjeros (GALVÁN, 2011b). Así, como rasgo distintivo del tratamiento argumental y la selección léxica de las referencias al presidente, $A y B$ demostraba una marcada animosidad.

En relación al análisis específico de las enunciaciones referidas a la persona de Frondizi, llama la atención que durante el gobierno de la "Revolución Libertadora" y las primeras semanas luego de su asunción proliferaban las referencias al "doctor" Frondizi, que rápidamente se dejarían de lado y se reemplazarían, en los números posteriores al denominado "gran cambio", por apelativos que lo calificaban de delincuente, inmoral traidor o diabólico. Este estilo marcadamente agresivo comienza a mediados de 1958 y aumenta de forma gradual hasta fines de 1960, cuando el punto alcanzado favorece la decisión presidencial de clausurar la publicación. En este sentido, por ejemplo, en el contexto de los debates por la "Laica o la Libre", el semanario había hecho referencia a un "aquelarre laico" ( $A y B$, nro. 109, 15/07/58). Asimismo, en relación a los sectores aliados al presidente y "enemigos" de la Patria, se apelaba a metáforas intimidatorias tales como "el imperio tenebroso de la masonería" ( $A y B$, nro. 156, 09/06/59), y, en este marco, se hacía mención al "diabólico proceso de entrega nacional" liderado por Frondizi ( $A y B$, nro. 227, 26/10/60). Más allá de las sugerentes apelaciones de estas metáforas al campo semántico de lo diabólico y anticristiano, el recurso de la ironía y el sarcasmo también fue asiduo en las páginas de $A y B^{x x v i}$. También se utilizaban construcciones irónicas para denigrarlo frente a los ojos del lector, sin caer en el insulto burdo $^{\text {xxvii }}$

En conjunto, tanto el estilo como la retórica de $A y B$ demonizaban y degradaban moralmente a Frondizi, cuestionando de esta manera no sólo su moralidad, sino también su legalidad como primer mandatario e invitando a las Fuerzas Armadas a realizar un golpe en su contra. Complementariamente, las representaciones iconográficas de Arturo Frondizi apelaban a estereotipos denigrantes que remarcaban la falta de autoridad, el "afeminamiento político" y la alteridad respecto a un tipo ideal de líder.

De este modo, las iconografías del presidente Frondizi se abocaron a construir una 
imagen del presidente que expresase la desaprobación de sus políticas. En esto, se buscó asimilar cualidades que se le atribuían a Frondizi, tales como ineptitud, ineficacia, inmoralidad, a características físicas monstruosas y enfermizas. Así, una de las más llamativas fórmulas que se utilizó para representar al presidente fue la de los monstruos o seres deformes. En occidente, la figura del monstruo se ha utilizado históricamente para representar al otro, oscuro, peligroso en algún sentido para la cultura dominante que lo piensa (BURKE, 2005, pp. 155-162; FERRO, 2008, p 39). La deformación física que usualmente conlleva el carácter monstruoso del representado tiene un correlato en los juicios morales que éste suscita (BURKE, 2005, p. 171; FERRO, 2008, pp. 63-68). De modo similar, las imágenes infamantes, es decir de sujetos deformes o en situaciones vejatorias se han asociado desde fines del siglo trece con condenas de orden legal (FREEDBERG, 1989, p. 287).

Así, valiéndose de estas tradiciones inherentes a la cultura occidental, $A y B$ optó por estas fórmulas iconográficas en diversas ocasiones, al momento de representar al "Frondizi traidor". Así, la figura 4 muestra al presidente como una gallina desplumada con dos cabezas, dando cuenta en ello del supuesto carácter esquizofrénico y ocultador de Frondizi. De la misma manera, se apeló recurrentemente a motivos iconográficos que remitían a estereotipos de marginales, como la nariz ganchuda de las imágenes de judíos. Más allá de que la nariz haya sido el rasgo más monstruoso de esta figura masculina, antítesis del ideal nacionalista, el cuerpo flaco, flácido y encorvado de Frondizi (que en algunas ocasiones hasta era mostrado desnudo para enfatizar su malformación (Figs. 4, 5 y 6); constituyó un elemento más que no sólo daba cuenta de lo horroroso sino también de la falta de vigor y virilidad, valores a los que -como ya se explicó en el caso de Tacuara- los nacionalistas guardaban mucha estima.

Asimismo, en ocasiones este cuerpo débil y afeminado ha sido asociado con la enfermedad. Este es el caso de las figuras 7 y 6 . En la primera de éstas, el presidente es representado como un Quijote malformado, montando en solitario un caballo igualmente raquítico. Aquí, el caricaturista se vale del recurso de la ironía al hacer uso de una escena ecuestre, tradicionalmente utilizada para representar figuras de poder en relación con valores hidalgos y viriles (BURKE, 2005, pp. 77, 85-86), pero que en este caso muestra un caballero débil y de aspecto enfermizo. Además, la referencia al Quijote sugiere la presencia de una enfermedad mental que condena a este "caballero" al delirio. Por otra parte, la figura 6 exhibe el cuerpo escuálido y desnudo de Frondizi que aparece "apestado" de bichos con forma de 
hoces y martillos. Esta figura acusa que el presidente ha sido "infectado" por "bichos rojos" con forma del símbolo comunista. Este presupuesto, hace referencia a la acusación de que las políticas a favor de los capitales extranjeros de Frondizi respondían a una compleja estrategia de ocultamiento de su calidad de agente de comunista, a partir de la cual buscaría encender la mecha revolucionaria marxista en el país. En este sentido, recuperando las metáforas biológicas del "miedo rojo" de principios de siglo (WECHSLER; CATARUZZA; GENÉ, 2005, p. 82), se jugaba con la idea de enfermedad e intoxicación.

Estas representaciones de Frondizi no sólo se oponen a los ideales de belleza, salud y virilidad de los nacionalistas sino que coinciden - por contraposición- con su idea clásica de enemigo: seres cobardes, afeminados, viejos, débiles, enfermizos y “chochos". Esta manera de representar al opositor político buscaba asociar el desorden físico general (como ya se había visto en el caso de las figuras monstruosas o en situaciones injuriosas) con el desorden moral (FINCHELSTEIN, 2002, p. 125). En este sentido, esta serie de imágenes de Frondizi coincide con las acusaciones - mencionadas más arriba- que recibió de traidor y deshonesto, luego del "gran cambio". Conservando este sesgo, otras figuras de Frondizi optan simplemente por enfatizar en los aspectos humillantes, vergonzosos, condenables y ridículos del presidente. De este modo, los dedos acusatorios de la figura 8 , que se suman en esta última a la postura corporal del acusado que denota vergüenza y humillación o la desnudez horrorosa de la figura 5, que roza el ridículo, contribuyen a construir la imagen de un Frondizi infrahumano.

Ligada a estas caracterizaciones de inmoral e infrahumano se encuentra otra serie de imágenes que exhiben al presidente como bestia. Teniendo en cuenta que las representaciones iconográficas que se valen de figuras de animales apelan a la deshumanización de los representados con el fin de poner en duda la calidad moral de los representados (BURKE, 2005, p. 171), la selección de los animales para construir estas metáforas es singular. En este sentido, las iconografías de Frondizi en $A y B$, construidas sobre la base de figuras de animales, se caracterizaron por optar por una fauna de especímenes considerados "bajos", parasitarios, indignos, serviles, estúpidos o carroñeros. Así, el presidente adoptó la forma de mula o burro (figura 9), de cerda (figura 10a), de parásito (figura 11), de rata (figura 12), de cuervo (figura 10b), de animal muerto (figura 13) y de perro (figura 14).

Partiendo de que las iconografías de burros o mulas se relacionan con la estupidez o la 
incapacidad del representado (FERRO, 2008, p. 75), se puede conjeturar que la representación de Frondizi como ese animal enfatiza su incapacidad para dirigir al país. Por otro lado, respecto de la situación relacional de Frondizi con los poderes extranjeros -algo ampliamente cubierto por $A y B$ en su plano textual-, las representaciones del presidente como perro, animal muerto y cerda guardan estrecha relación con las denuncias contra la "entrega". Así, tradicionalmente el perro se ha utilizado para representar lealtad (HALL, 1974, p. 105), sin embargo, el resto de los elementos que componen la figura 14 completan el sentido de este concepto con connotaciones negativas. Efectivamente, el "perro" Frondizi es leal, pero a sus verdaderos amos: los capitales norteamericanos y británicos, representados por dos manos que llevan del collar al perro y cuyas mangas de camisa tienen el diseño de las respectivas banderas. Asimismo, la frase al pie de la imagen termina de aclarar la situación descripta: “Ambos lo llevan del collar!". De este modo, se invierten las connotaciones positivas de la imagen canina y se hace uso de otras de sus implicancias: el servilismo, la sumisión.

Por otra parte, la representación de Frondizi como una cerda que amamanta a sus cachorros, que no son más que el "Tío Sam" (representativo de Estados Unidos), "John Bull” (ícono de Gran Bretaña), un militar y un intelectual, da cuenta del cambio de percepción del semanario sobre una misma característica del presidente. Tradicionalmente, las imágenes de cerdos como representaciones denigrantes fueron asociadas a los judíos, a la monarquía durante la Revolución Francesa o a los capitalistas, por ejemplo, en las obras de Georg Grosz y Diego Rivera (BURKE, 2005, p. 171). En igual sentido, la imagen de la "cerda" Frondizi amamantando a los enemigos de la nación buscaba despertar en el lector asociaciones repulsivas.

Del mismo modo, la imagen de Frondizi como res (figura 13) busca una nueva e ingeniosa forma de representar al presidente con connotaciones humillantes, pero a la vez destacando la causa "extranjerizante" de la desgracia del representado. En este caso se enfatiza particularmente el resultado de la entrega y de la "mala" gestión, que repercuten en la falta de legitimidad de la que se acusa al presidente. Éste había sido elegido no sólo en un marco de "democracia restringida" (con la proscripción del peronismo mayoritario), sino que había ganado las elecciones sobre la base de un programa político, un "contrato" con sus electores, que después incumplió. Así, lo que interesa de esta imagen es que, más allá de representar a un animal muerto, se encuentra en una postura abandonada y absolutamente 
pasiva, colgando de un gancho. Esta postura corporal remite a la tradición de imágenes infamantes, a la que se hizo referencia más arriba, en relación a las figuras de monstruos. Las imágenes infamantes, generalmente asociadas a la condena legal o moral, ostentan signos evidentes de oprobio, a manera de castigo. Así, quemar o colgar imágenes de los juzgados por acciones delictivas era una manera de deshonrar públicamente al condenado. Particularmente, aquellos acusados de fraude o traición se representaban colgados (FREEDBERG, 1989, p. 297). La relación de la imagen de Frondizi con esta tradición de origen medieval -cuyas huellas subsisten aun hoy- se explica mejor con la nota que la viñeta de la res pretendía ilustrar. En ella se cuestiona, nuevamente, la legitimidad del gobierno de Frondizi que no sólo ha engañado al para llegar al poder y ha entregado la riqueza nacional a los poderes extranjeros, sino que ahora tampoco era capaz de mantener el orden y la paz en el territorio nacional. En este sentido, el redactor interpela a los militares para que tomen conciencia de que Frondizi es un peso muerto que cuelga de sus espaldas: "Los generales lo sostienen pero no lo apoyan (...) y el primer magistrado se deja sostener porque si este apoyo físico le faltara, caería en el vacío" ( $A y B$, nro. 169, 08/07/59).

En este misma línea, $A y B$ también se valió de ratas e insectos (Figs. 12 y 11) para suscitar en el lector asociaciones repelentes, derivadas de ideas tales como la putrefacción, parásitos, enfermedad y contagio. Asimismo, la figura del cuervo (Fig.10a) no dista de estas asociaciones. Al escoger un ave de carroña para representar a Frondizi, el caricaturista en primer lugar está remitiendo al lector a escenas desoladas de destrucción y muerte (marco más común en el que se representa a este tipo de animales), como se percibe en el horizonte de esta imagen, en la que aparecen cadáveres humanos en un segundo plano y se apela al refrán popular, "Cría cuervos y te sacarán los ojos", para sintetizar el carácter de traidor del presidente. En este sentido, con la mencionada figura se busca advertir sobre el futuro sombrío que se estaría proyectando en el horizonte del proceso de entrega que iniciara Frondizi con la firma de los primeros contratos petroleros.

En síntesis, la estrategia "azulblanquista" de presentar al presidente Frondizi como un enemigo, opuesto a los valores y cualidades nacionalistas, se condensó en una figura de infrahombre que se contraponía al ideal de belleza y heroicidad masculinas. De esta manera, a partir de la antítesis, no sólo se criticaba al opositor político sino que se le daba forma a una identidad propia en oposición a una alteridad que reunía todo aquello que se consideraba 
digno de rechazo y desprecio.

La importancia del estereotipo masculino negativo descansa así en su poder como organizador de un campo político en constante transformación, donde parecía indispensable hacer explícitas y claras las listas de enemigos y los valores loables que se esperaba encontrar en un militante nacionalista. Así, por ejemplo, en este sentido, $A y B$ había terminado por abrir sus propuestas políticas a sectores de la izquierda nacional que hasta pocos años antes habían sido considerados opositores ${ }^{\mathrm{xxviii}}$. En ese contexto, como se mencionó en el apartado anterior, también se recuperaron algunas figuras masculinas de izquierda (como el sindicalista Ongaro o el "Che" Guevara), en un marco representacional que exaltaba valores positivos como valentía, idealismo, etc., mientras omitía ahondar en las ideologías específicas de estos "héroes".

En suma, debido a este relajamiento de los límites entre las categorías de aliados y enemigos políticos, se volvió relevante para $A y B$ definir los elementos personales que reunía un "traidor a la nación y al pueblo" (como ocurrió en el caso del presidente Frondizi), en oposición a quienes, como ellos mismos, anteponían el interés general de la nación en su conjunto.

Así, teniendo en cuenta las tres etapas de $A y B$ y los boletines de Tacuara, dos imágenes contrapuestas de hombre parecen haber prevalecido en las representaciones del discurso nacionalista: el héroe viril, fuerte, capaz de liderar a las masas y de sacrificarse por la nación y su antítesis, el desviado, el monstruo, ese ser infrahumano que encarnaba en sus particularidades físicas todas sus falencias y vicios morales. Si la primera de estas imágenes se remite al ideal de heroicidad de los nacionalistas de 1930, a los fascismos europeos y, más remotamente, al estereotipo masculino burgués del siglo dieciocho, la segunda encuentra sus principales antecedentes en los desviados sociales de los albores de la modernidad (judíos, gitanos), rodeados de motivos tales como la fealdad física, la enfermedad, el nerviosismo, el afeminamiento, la suciedad, la desproporción física, la cobardía (MOSSE, 1996).

Estos antecedentes repercuten, en ambos casos, en los significados de los elementos estéticos que componen cada uno de los estereotipos. En este sentido, mientras que la belleza, la actitud corporal proactiva, la mirada segura puesta en el horizonte y el sacrificio representan hidalguía, virilidad, patriotismo y, en conjunto, construyen un modelo positivo a imitar, la debilidad y deformidades físicas, la fealdad y las carencias en honor, higiene, 
virilidad y moderación de las pasiones primarias, dan cuenta de ilegalidad, depravación moral y refieren a una especie subhumana, sólo incorporable a este imaginario bajo connotaciones negativas tales como la amenaza de la otredad, en el sentido de lo "extranjerizante", de aquello que atenta contra la identidad propia.

\section{Conclusiones}

Las transformaciones sociales, políticas e ideológicas que sobrevinieron en Argentina durante la larga década del sesenta repercutieron en las identidades e ideologías de los principales actores del escenario político. Entre éstos, los nacionalistas de derecha se vieron particularmente afectados. Debido a ello, el período que va desde 1956 hasta 1969 se caracterizó por un constante intento por reacomodarse en el nuevo campo de fuerzas y de redefinirse no sólo en cuanto a programas y objetivos políticos, sino también en cuanto a su propia identidad.

Este proceso se rastreó en el presente trabajo en las publicaciones periódicas nacionalistas más representativas del nacionalismo de la época: el semanario político $A y B$ y los boletines de difusión de las agrupaciones juveniles Tacuara. En estas revistas, el proceso descripto más arriba estuvo signado por la profusión de estereotipos masculinos que (tanto a través de las imágenes gráficas como de los textos verbales) se dispusieron ante los lectores con objetivos claramente definidos.

En este sentido, entre las numerosas representaciones de la figura masculina en estas publicaciones, predominaron dos estereotipos concretos que sirvieron como homogeneizadores de las representaciones acerca de un "sí-mismo" y de una alteridad y como organizadores de roles políticos. Así, en las páginas de los boletines Tacuara y de AyBII (cuyos lectores modelos eran más jóvenes) emergió un exponente del militante nacionalista ideal que cumplía con los requisitos de virilidad, heroísmo, fortaleza y sacrificio en los que se pretendía educar al nuevo tipo de militante nacionalista. Para la construcción de este ideal de belleza y heroicidad masculino, se retomaron viejas tradiciones del revisionismo histórico y de los nacionalistas argentinos de la primera mitad del siglo veinte, pero en esta figura también se oían los ecos de otras tradiciones más lejanas geográficamente, como por ejemplo 
los fascismos europeos.

Estas tradiciones, junto con otras aun más distantes tanto temporal como geográficamente influyeron, asimismo, en la formación de la antítesis de este ideal de belleza y militancia nacionalista. De esta manera, el monstruo, la bestia, el deforme (retratado principalmente en las páginas de $A y B$ ) era un ser infrahumano que parecía reflejar en sus características teratológicas su ineptitud política para defender los intereses nacionales, que tan bien protegía el militante nacionalista, que -en este ropaje idealizado- parecía un caballero medieval protegiendo a su dama. Este estereotipo negativo, que encarnó principalmente en la figura de Frondizi, era funcional -más allá del ejemplo concreto- para definir con exactitud los límites de los aliados políticos posibles, los ex simpatizantes y los adversarios. Con esta estrategia, los nacionalistas intentaron esclarecer para sus lectores el dinámico campo político en el que pretendían actuar y, al mismo tiempo, buscaron reforzar la identidad propia a partir de su opuesto, en una época caracterizada por profundas crisis de identidades políticas.

\section{Referencias bibliográficas}

AAVV. Homenaje a Marcelo Sánchez Sorondo. Buenos Aires: Jorda, 1992.

ADAM, P. El arte del Tercer Reich. Barcelona: Tusquets, 1992.

ALTAMIRANO, C. Peronismo y cultura de izquierda (1955-1965), Latin American Studies Center: Mimeo, 1992.

BUCHRUCKER, C. Nacionalismo y Peronismo. La Argentina en la crisis ideológica mundial (1927-1955). Buenos Aires: Sudamericana, 1999.

BURKE, P. Visto y no visto. El uso de la imagen como documento histórico. Barcelona: Crítica, 2005.

BURUCÚA, J. E. Historia y ambivalencia. Ensayos sobre arte. Buenos Aires: Biblos, 2006. 2002.

Historia, arte, cultura. De Aby Warburg a Carlo Ginzburg. Buenos Aires: FCE,

CANDIANO, L. David Viñas y la traición Frondizi. De Contorno a Dar la cara. In: II CONGRESO INTERNACIONAL DE CUESTIONES CRÍTICAS, Actas del congreso, Rosario, 2009. http://www.celarg.org/int/arch_publi/candiano_acta.pdf 
CHARTIER, R. Inscrever \& apagar. São Paulo: Editora Unesp, 2007.

DEVOTO, F. J. Nacionalismo, fascismo y tradicionalismo en la Argentina moderna. Una historia. Buenos Aires: S. XXI, 2006.

DO NASCIMENTO GARCIA, S. Revista Careta: um estudo sobre humos visual no estado novo (1937-1945) Tesis (Maestría en Historia), Unesp, Assis, 2005.

EHRLICH, L. Rebeldes, intransigentes y duros en el activismo peronista, 1955-1962. Tesis (Maestría en Ciencias Sociales)- Instituto de Desarrollo Económico y Social, Universidad Nacional de General Sarmiento, Buenos Aires, 2011.

FERRO, G. Barbarie y civilización. Sangre, monstruos y vampiros durante el segundo gobierno de Rosas. Buenos Aires: Marea, 2008.

FINCHELSTEIN, F. Fascismo Transatlántico. Ideología, violencia y sacralidad en Argentina y en Italia, 1919-1945. Buenos Aires: FCE, 2010.

Fascismo, liturgia e imaginario. El mito del general Uriburu y la Argentina nacionalista. México DF: FCE, 2002.

FREEDBERG, D. El poder de las imágenes. Cátedra: Madrid, 1989.

GALVÁN, M. V. O Movimento Nacionalista Tacuara e suas ramificações: uma análise das suas representações figurativas. In: BEIRED, J.L.B.; BARBOSA, C.A.S. (orgs.), Política e identidade cultural na América Latina, São Paulo: Cultura Acadêmica, 2010, pp. 91-112.

"El 'país real' de Azul y Blanco y 2da República. La relación de los semanarios nacionalistas con el Peronismo durante las presidencias de Aramburu, Frondizi y Guido". In: XIII JORNADAS INTERESCUELAS/ DEPARTAMENTOS DE HISTORIA, 2011. Anales de las Jornadas. San Fernando del Valle de Catamarca, 2011a.

. "El nacionalismo argentino (1956-1961): observaciones teórico-metodológicas a partir de la reconstrucción de un discurso nacionalista en el semanario Azul y Blanco". In BOHOSLAVSKY, E. Las derechas en el cono sur, siglo XX. UNGS. $2011 \mathrm{~b}$. http://www.ungs.edu.ar/areas/publicaciones/420/las-derechas-en-el-cono-sur-siglo-xx.html

El Movimiento Nacionalista Tacuara y sus agrupaciones derivadas: una aproximación desde la historia cultural. Tesis (Maestría en Sociología de la Cultura), IDAES/ UNSAM, Buenos Aires, 2008.

Publicaciones periódicas nacionalistas de derecha: Las tres etapas de Azul y Blanco (Azul y Blanco 1956-1960. Segunda República 1961-1963, Azul y Blanco segunda época- 1966-1969) [en línea]. Tesis (Doctorado en Historia) - Universidad Nacional de La Plata, Facultad de Humanidades y Ciencias de la Educación, La Plata, 2012. http://www.memoria.fahce.unlp.edu.ar/tesis/te.456/te.456.pdf

GENÉ, M. Un mundo feliz. Imágenes de los trabajadores en el primer peronismo 19461955. Buenos Aires: FCE-Universidad San Andrés, 2005. 
GOEBEL, M. Argentina's Partisan Past. Nationalism and the Politics of History. Liverpool: Liverpool University Press, 2011.

HALL, J. Dictionary of Subjects and Symbols in Art. New York: Icon Editions, 1974.

LVOVICH, D. EI Nacionalismo de Derecha. Desde sus orígenes a Tacuara. Buenos Aires: Capital Intelectual, 2006.

LVOVICH, D. Nacionalismo y Antisemitismo en la Argentina. Buenos Aires: Ediciones B, 2003.

MCGEE DEUTSCH, S. Las Derechas. La extrema derecha en la Argentina, el Brasil y Chile. 1890-1939. Bernal: Universidad Nacional de Quilmes Editorial, 2005.

MELON PIRRO, J. C. La prensa de oposición en la Argentina post-peronista. In: EIAL, n. 12, vol. 13 Julio-Diciembre, 2002.

El peronismo después del peronismo, Buenos Aires: Siglo XIX, 2009.

MOSSE, G. L. National Cemeteries and National Revival: the Cult of the Fallen Soldiers in Germany, Journal of Contemporary History. n. 1, vol. 14, pp. 1-20, 1979.

The Image of Man. The creation of modern masculinity. Oxford: Oxford University Press, 1996.

NAVARRO GERASSI, M. Los Nacionalistas. Buenos Aires: Editorial Jorge Álvarez, 1968.

ORLANDINI, J. E. Tacuara...hasta que la muerte nos separe de la lucha. Historia del Movimiento Nacionalista Tacuara 1957-1972. Buenos Aires: Centro Editor Argentino, 2008.

SARLO, B. La batalla de las ideas (1943 - 1973). Buenos Aires: Ariel, 2001.

SAXL, F. La vida de las imágenes. Madrid: Alianza, 1989.

SIGAL, S. Intelectuales y poder en Argentina. La década del sesenta. Buenos Aires: Siglo XXI, 2002.

SPEKTOROWSKI, A. Argentina 1930-1940: nacionalismo integral, justicia social y clase obrera, en EIAL, no. 1, vol. 2, 1990.

SPINELLI, M. E. Las revistas Qué sucedió en 7 días y Mayoría. El enfrentamiento en el antiperonismo durante los primeros años del 'frondizismo'. In: DA ORDEN, M. L.; MELON PIRRO, J. C. Prensa y peronismo. Discursos, prácticas, empresas 1943-1958, Rosario: Prohistoria, 2007, pp. 219-242.

STEIMBERG, O. Para una pequeña historia del lenguaje gráfico argentino, en Estilo de época y comunicación. Tomo 1. Buenos Aires: Atuel, 1997. 
TCACH, C. Capítulo I: Golpes, proscripciones y partidos políticos, en Nueva Historia Argentina. Violencia, proscripción y autoritarismo (1955-1976), Tomo IX. Buenos Aires, Editorial Sudamericana, 2003, pp. 17-62.

\section{TERÁN, O. Nuestros Años Sesenta. La formación de la nueva izquierda intelectual argentina 1956-1966. Buenos Aires: El Cielo por Asalto, 1993.}

WECHSLER, D.; CATTARUZZA, A.; GENÉ . Fuegos cruzados. Representaciones de la Guerra Civil en la prensa argentina (1936-1940). Fundación Provincial de Artes Plásticas Rafael Botí, Diputación de Córdoba, 2005.

\section{Notas}

\footnotetext{
${ }^{i}$ Mientras que $A y B$ como grupo surge en 1956, con la fundación del semanario, Tacuara realiza su bautismo político en 1957.

${ }^{i i}$ La tacuara era una caña utilizada como arma para la lucha por los cuerpos de montoneras en el siglo XIX.

iii Los conflictos popularizados bajo el lema "Laica o Libre" describen las manifestaciones callejeras de estudiantes durante la presidencia de Arturo Frondizi, en las que docentes y miembros de la Iglesia católica se vieron enfrentados en torno a la cuestión de la reglamentación del artículo 28 del decreto 6403/55 que autorizaba a las universidades privadas a emitir títulos habilitantes para la práctica profesional, lo que implicaba concretamente que se abría la puerta para la creación de universidades privadas (principalmente bajo influencia de la Iglesia Católica) habilitadas para emitir títulos oficiales.

${ }^{\text {iv }}$ La mayoría de los jóvenes militantes del MNT habían sido reclutados, en un comienzo, en prestigiosos colegios privados católicos de la elite porteña.

${ }^{v}$ El grupo $A y B$, encabezado por Marcelo Sánchez Sorondo, se había iniciado en política con los Cursos de Cultura Católica durante la década de 1920, momento desde el cual permanecieron activos en la escena política argentina (AAVV, 1992).

vi Algunas características de su diagramación daban cuenta de que $A y B$ era, efectivamente, un semanario producido por nacionalistas y pensado para el microclima de intelectuales nacionalistas, donde buscó erigirse como espacio de discusión y síntesis de su pensamiento. En relación con esto, las páginas del semanario cedían un espacio de publicidad para otros semanarios y libros nacionalistas, se publicaban opiniones de intelectuales nacionalistas en la sección de cartas de lectores y avisos sobre presentaciones de libros, reseñas bibliográficas, cursos, charlas, convocatorias a actos o misas, comunicados de agrupaciones políticas nacionalistas y conferencias de esta misma tendencia.

vii Por "imagen" se debe leer "caricatura política", debido a que la fotografía no cumplió un rol relevante en esta primera etapa (entre 1956 y 1963 se pueden contar no más de cinco fotos en total, todas ellas pertenecientes a archivos personales y siempre utilizadas de forma ilustrativa de ciertos personajes "dignos de destaque", generalmente, intelectuales o políticos nacionalistas).

${ }_{\text {viii }}$ Los caricaturistas de esta publicación fueron reemplazados en varias oportunidades debido a cambios en la orientación de las críticas a los gobiernos. Así, en octubre de 1956 se reemplazó al dibujante Santiago, más concentrado en las críticas a las instituciones culturales liberales de la "Revolución Libertadora", por el conocido caricaturista Lino Palacio. Éste, a su vez, dejó el grupo con el cisma editorial de 1958, causado por la adscripción de muchos "azulblanquistas" fundadores al gobierno frondizista (aun después del "gran cambio" de este gobierno con simpatías nacionalistas que viró más tarde su política en favor de los capitales internacionales). Los nuevos caricaturistas a partir de ese momento serían la dupla del "Erizo" conformada por André Delbaerre y Jean-Henri Azéma, dos ex colaboracionistas nazis, refugiados ilegalmente en el país (GALVÁN, 2012, pp. 48-50).

ix Las secciones más importantes del semanario, "7 días de política" (tapa) y "7 días en los gremios" (contratapa), eran resumidas de una manera más amena, sucinta y, muchas veces, en un tono irónico o humorístico en las secciones de las páginas 2 y 3: "Glosas políticas", "El tablado de los políticos", "Visto y oído", "Topolino gremial", "Información topo" y "Politiquerías" . A esta lista se agregaban "Cartas al director" y
} 
"Seis preguntas a...", secciones a través de las cuales se dejaba oír tanto la voz de los lectores como de "intelectuales de renombre", que en su mayoría eran representantes del pensamiento nacionalista pero no exclusivamente. Asimismo, algunos números contaron con notas escritas por corresponsales extranjeros o intelectuales nacionalistas de renombre que escribían "colaboraciones especiales". Más allá de estos y algunos otros casos excepcionales -en los que la firma del autor se ponía al pie de la colaboración especial, la entrevista (en este caso, el nombre del entrevistado encabezaba la nota) o la carta de lector-, la mayor parte de las notas no estaban firmadas, por lo que el director se hacía responsable explícitamente del contenido de cada una de ellas, reforzando así la univocidad de la publicación.

${ }^{\mathrm{x}}$ De hecho compartían la misma imprenta con publicaciones peronistas y otras nacionalistas como por ejemplo Palabra Argentina, Rebeldía, Palabra Prohibida, Línea Dura, El Guerrillero, El Hombre y Norte (y también la trotsko-peronista Palabra Obrera). La imprenta en cuestión (cuyos trabajadores eran, aparentemente, todos peronistas) era la conocida "The Standard Publishing \& Co.", también llamada "The Standard" o "Alemann y Cía", de propiedad de la familia tradicional porteña Alemann, también dueña del periódico liberal alemán Argentinisches Tageblatt (EHRLICH, 2011, p. 30).

${ }^{x i}$ El Plan de Conmoción Interna del Estado (CONINTES) otorgaba facultades judiciales al Poder Ejecutivo y autorizaba el involucramiento de las Fuerzas Armadas en la represión interna. Pese a que éste se había originado en la inmediata posguerra y como resultado directo de la Guerra Fría (1948), fue ejecutado por el gobierno de Frondizi, con el fin de poder encarcelar a sospechosos de ser militantes izquierdistas o peronistas con la participación de las Fuerzas Armadas (TCACH, 2003, p. 34).

xii Así, $A y B$ argumentaba que las concesiones extremas a los capitales foráneos tenían el objetivo oculto de conseguir aliados poderosos que le posibilitasen a Frondizi sustentarse en el poder frente a la resistencia del pueblo traicionado: "El estratego del marxismo se sostiene por apoyo del dólar y la libra" ( $A y B$, nro. 134, 06/01/59). Sin embargo, esto era parte de un ardid más amplio que consistía en llevar al país al estado de crisis previo a la revolución comunista $(A y B$, nro. 160, 07/07/59).

xiii “Consigna para obreros y empresarios" (2da República, nro. 13, 27/06/62), "Este caos o nuestra revolución" (2da República, nro. 31, 08/11/62), "La revolución nacional exige” (2da República nro. 30, 31/10/62), etc.

xiv Ver, por ejemplo, "Confesión de un obrero libre" en 2 da República, nro. 11, 06/06/62.

${ }^{\mathrm{xv}}$ Ésta estaba constituida principalmente por la venta del periódico mismo (cuyo monto se reinvertía totalmente en la edición, debido a que ninguno de los que escribían y hacían $A y B$ cobraban por su trabajo), a lo que le seguían las colaboraciones privadas y la reventa del papel de ediciones viejas.

${ }^{x v i}$ A las que debería sumarse el cambio de tamaño de la hoja al tipo berlinés (menor que la anterior) y una extensión menor del cuerpo de cada nota.

xvii De hecho, el incremento en el número de páginas derivó en una multiplicación de las secciones y columnas fijas con el siguiente recorrido de lectura: tapa (con resumen de los contenidos o titular principal), cartas de lectores, aclaraciones del redactor, editorial, "Lo que pasa" (columna de política nacional que estaba acompañada de una serie de fotografías dispuestas secuencialmente en el encabezado ${ }^{\text {xvii }}$ ), columna gremial, universidad, sección internacional, "Semana Cultural", "Deportes", "Orígenes del Nacionalismo Argentino" (columna de historia), "La página de Marenco" (documentos de cultura gauchesca), contratapa de humor. A este recorrido más o menos estable se le sumaban notas específicas de economía, notas de opinión en la parte central sobre la temática que consideraban preponderantemente relevante esa semana y se incluían algunas encuestas de opinión y entrevistas. Frente a estas diferencias aparecen como rasgos de continuidad las entrevistas a personalidades cercanas al pensamiento nacionalista o con intereses políticos en común, los anuncios de conferencias homenajes y actos nacionalistas y las reseñas y propagandas de libros de esa tendencia.

xviii Luego de la renuncia del nacionalista tradicional, Ricardo Curutchet, Marcelo Sánchez Sorondo reasumió por un tiempo su cargo original y luego delegó estas funciones en Luis Rivet.

${ }^{\text {xix }}$ Muchos nacionalistas se sintieron compelidos política y socialmente por el compromiso por los pobres y en contra de las desigualdades sociales, recientemente hecho explícito por la Iglesia Católica a través de la encíclica papal Populorum Progressio (26 de marzo de 1967). Con este documento típicamente posconciliar, se exhortaba desde la Iglesia jerárquica a los fieles a seguir estos preceptos a favor de la equidad, la justicia social, la caridad y el libre desarrollo de los pueblos, distanciados de la opresión de los países centrales.

${ }^{\mathrm{xx}}$ Las diferencias y similitudes entre los diversos boletines de las agrupaciones Tacuara no son abordadas aquí debido a que estas ya han sido tematizadas en GALVÁN, 2010 y en GALVÁN, 2008. De cualquier manera, aquellas no son relevantes para los objetivos de este trabajo ya que todos los boletines incluidos aquí presentaban un lector modelo prácticamente idéntico. 
Os homens do imaginário nacionalista: representações da masculinidade em publicações periódicas nacionalistas de direita argentinas durante a longa década de sessenta (1956-1969)

${ }^{x x i}$ Estas son que fórmulas, vectores o eslabones de emotividad que posibilitan la convivencia de distintos niveles de racionalidad en una imagen. Su análisis, en el marco del método iconográfico, arroja claridad, en última instancia, sobre las experiencias básicas de la vida social en la cultura occidental (BURUCÚA, 2006 y 2002).

xxii Según Saxl (1989), la Pathosformel del hombre luchador, el hombre que pelea con la bestia, en sus diversas versiones con armas primitivas (blandiendo una maza o un palo) o presentando una disposición del cuerpo que lo ubica en situación de caza o de lucha contra fuerzas no humanas, nació en el arte de la Mesopotamia con la figura de Mitras y habría alcanzado su máxima expresión en las representaciones griegas de Hércules. Burucúa continúa la serie y muestra el resurgimiento de esta en el arte de la Shoa, encarnando en este caso a los verdugos (BURUCÚA, 2006: 188).

xxiii La reelaboración icónica del cristianismo afectó a otra Pathosformel que ya aparecía en la antigüedad: la del esclavo, la del vencido, la del hombre agobiado por el trabajo y la derrota. También en el Bajo Medioevo y en el Renacimiento los cristianos recuperaron esa Pathosformel pero le otorgaron la dignidad del sufriente, de la víctima de las injusticias (BURUCÚA, 2006, p. 189).

${ }^{x x i v}$ Fondo CEN, Caja 1424; Clarín, 29 de enero de 1963; Clarín, 26 de enero 1963; La Luz, 1 de enero de 1963; La Luz, 31 de enero de 1963; Argentinisches Tageblatt, 1 de enero de 1963; El Litoral, 1 de febrero de 1963; El Mundo, 2 de febrero de 1963; Primera Plana, 3 de febrero de 1963; Nueva Sión, 8 de febrero de 1963; La Nación, 11 de febrero de 1963; Clarín, 11 de febrero de 1963; La Prensa, 11 de febrero de 1963; y Clarín, 11 de marzo de 1963.

${ }^{\mathrm{xxv}}$ Tacuara. Vocero de la Revolución Nacionalista, 1959; Ofensiva, No. 11; Tacuara. Vocero de la Revolución Nacionalista, No. 8, año 1962 (?); Mazorca, No. 1 y Mazorca, No. 3, edición tributo a este personaje.

${ }^{x x v i}$ Fue común el uso de las comillas para los términos "gobierno" y "legalidad" (ver, por ejemplo, $A y B$, nro. 217, 15/08/60) o "Tenemos Fuerzas Armadas... de paciencia" ( $A y B$, nro. 220, 07/09/60), que ponían en duda la positividad de los conceptos en sí.

xxvii Como ejemplos de esto es posible hallar frases del tipo "El piadoso villano" ( $A y B$, nro. 231, 23/11/60) o "se sabe que el primer ministro israelí se limitó a enviar una carta personal al paladín de la dignidad y el honor argentinos, Arturo Frondizi” ( $A y B$, nro. 216, 09/08/60) y construcciones sarcásticas: “...queda constituida la comisión que, bajo la presidencia del subsecretario de Defensa Nacional, estudiará las actividades comunistas en el país y el modo de combatirlas; no hay por qué preocuparse más ( $\mathrm{Oh}$, si a los Romanoff se les hubiese ocurrido lo mismo!)" ( $A y B$, nro. 227, 26/10/60).

xxviii En los últimos números de AyBII, sin desestimar la influencia de Populorum Progressio (que, en última instancia, legitimó la opción latinoamericanista y la crítica social progresista entre los católicos, aun los de derecha), fue el fuerte compromiso político con un cambio auténtico que terminase con la ya agobiante dictadura de Onganía lo que terminó por definir a los "azulblanquistas" a favor de una alianza "apartidista" e inclusiva. Esto abarcaba incluso a la izquierda nacional (AyBII, nros. 116, p. $10,10 / 06 / 69$ y 65, pp. 2 y 3, 18/06/68).

Recebido em maio/2012.

Aprovado em setembro/2012. 